\title{
Penetapan Wali Hakim Sebagai Pengganti Wali Adlal Yang Tidak Menyetujui Pernikahan Anaknya
}

\author{
Elang Darmawan ${ }^{1}$, Ahmad Baihaki $^{2}$, Otih Handayani ${ }^{3}$ \\ ${ }^{123}$ Fakultas Hukum, Universitas Bhayangkara Jakarta Raya \\ Email: elangdar@gmail.com, baihaki.vision@gmail.com,otih.handayani@gmail.com
}

Article info

Received: Ags 16, $2021 \quad$ Revised: Sep 14, $2021 \quad$ Accepted: Oct 10, $2021 \quad$ Published: Dec 9, 2021

DOI: https://doi.org/10.31599/krtha.v15i2.702

Keywords : Guardian Judge, Guardian Adlal, Marriage Mechanism

Abstract : Humans are gifted by God Almighty to be able to reproduce and continue their offspring. The marriage order in Indonesia is regulated in the rules of marriage law. including Law no. 1 of 1974 concerning Marriage and the Compilation of Islamic Law (KHI). In the KHI it is stated that the guardian of marriage in marriage is a pillar that must be fulfilled for the prospective bride who acts to marry her. Problems occur when lineage guardians are reluctant to marry off their children due to parental considerations regarding the seeds, bebet and the weight of the prospective son-in-law. This study aims to examine the application of positive legal rules or norms which are then linked to the discussion that is the subject of discussion. Normative juridical law research is carried out by examining formal legal rules such as laws, regulations and literature containing theoretical concepts. The results of the study describe that the determination of the guardian of the judge as a substitute for the guardian of Adlal can be done by using the correct marriage mechanism, the marriage cannot be prevented or canceled because the bride and groom have met the requirements of marriage and there is no marriage ban.

Kata kunci : Wali Hakim, Wali Adlal, Mekanisme Perkawinan

Abstrak : Manusia dianugerahi oleh Tuhan Yang Maha Esa untuk dapat berkembang biak dan meneruskan keturunannya. Tata tertib perkawinan di Indonesia diatur dalam kaidah-kaidah hukum perkawinan. diantaranya Undang-undang No. 1 Tahun 1974 tentang Perkawinan dan Kompilasi Hukum Islam (KHI). Di dalam KHI dinyatakan bahwa wali nikah dalam perkawinan merupakan rukun yang harus dipenuhi bagi calon mempelai wanita yang bertindak untuk menikahkannya. Permasalahan terjadi manakala wali nasab enggan menikahkan anak disebabkan oleh pertimbangan orang tua mengenai bibit, bebet dan bobot calon menantu. Penelitian ini bertujuan untuk mengkaji penerapan kaidah-kaidah atau normanorma dalam hukum yang positif yang kemudian dihubungkan dengan pembahasan yang menjadi pokok pembahasan. Penelitian hukum yuridis normatif dilakukan dengan cara mengkaji aturan hukum bersifat formil seperti undangundang, peraturan serta literatur yang berisi konsep-konsep teoritis. Hasil penelitian mendiskripsikan bahwa Penetepan wali hakim sebagai pengganti wali Adlal bisa dilakukan dengan menggunakan meknisme perkawinan yang benar, perkawinan tidak dapat dicegah atau di batalkan sebab kedua mempelai sudah memenuhi syarat perkawinan dan tidak ada larangan perkawinan. 


\section{PENDAHULUAN}

Manusia dianugerahi oleh Tuhan Yang Maha Esa untuk dapat berkembang biak dan meneruskan keturunannya, yang mana menurut aturan hukum Indonesia harus terikat dalam suatu hubungan yang dinamakan perkawinan. ${ }^{1}$ Perkawinan bukan hanya menyatukan dua pasang manusia, yakni laki-laki dan perempuan, melainkan mengikatkan tali perjanjian yang suci atas nama Allah, bahwa kedua mempelai berniat membangun rumah tangga yang sakinah, tentram, dan dipenuhi oleh rasa cinta dan kasih sayang. Oleh karena, tata tertib perkawinan di Indonesia perlu diatur dalam kaidah-kaidah hukum perkawinan sebagai landasan dan pedoman hukum bagi seluruh warga negara Indonesia dalam suatu aturan yang tertulis.

Pasal 1 Undang-undang Nomor 1 Tahun 1974 tentang Perkawinan menyebutkan bahwa perkawinan adalah ikatan lahir batin antara seorang pria dengan seorang wanita sebagai suami istri dengan tujuan membentuk keluarga (rumah tangga) yang bahagia dan kekal berdasarkan Ketuhanan Yang Maha Esa. ${ }^{2}$ Menurut Pasal 2 Kompilasi Hukum Islam (KHI) adalah pernikahan, yaitu akad yang sangat kuat atau mitssaqan ghalidzan untuk mentaati perintah allah dan melaksanakannya merupakan ibadah. ${ }^{3}$ Terkait sah tidaknya suatu perkawinan diatur dalam pasal 2 ayat (1) Perkawinan adalah sah, apabila dilakukan menurut hukum masing-masing agamanya dan kepercayaannya itu; (2) Tiap-tiap perkawinan dicatat menurut peraturan perundang-undangan yang berlaku. ${ }^{4}$

Sementara menurut Pasal 4 Kompilasi Hukum Islam, Perkawinan dinyatakan sah apabila dilakukan menurut hukum Islam sesuai dengan pasal 2 ayat (1) Undang-Undang No. 1 Tahun 1974 tentang Perkawinan. Perkawinan baru dinyatakan sah apabila telah memenuhi syarat dan rukun perkawinan. ${ }^{5}$ Salah satu rukun perkawinan adalah keharusan adanya wali nikah. Wali nikah dalam perkawinan merupakan rukun yang harus dipenuhi bagi calon mempelai wanita yang bertindak untuk menikahkannya. ${ }^{6}$

${ }^{1}$ Hilman Hadikusuma, Hukum Perkawinan Indonesia Menurut Undang-undang, Hukum Adat, Hukum Agama, Jakarta: Mandar Maju, 1990, hlm 189

2 R. Subekti dan R. Tjitrosubidio, Undang-undang Nomor 1 Tahun 1974 Tentang Perkawinan, Jakarta: Pradnya Paramita. 2005. Hlm. 537

3 Adi Nur Rohman (2019). The Existence Of Maslahah Mursalah As The Basis Of Islamic Law Development In Indonesia. Krtha Bhayangkara, 13(2). https://doi.org/10.31599/krtha.v13i2.9

${ }_{4}$ Masri, E. (2019). Poligami Dalam Perspektif Undang-Undang Nomor I Tahun 1974 Tentang Perkawinan Dan Kompilasi Hukum Islam (KHI). Krtha Bhayangkara, 13(2). https://doi.org/10.31599/krtha.v13i2.7

${ }^{5}$ Pasal 14 Kompilasi Hukum Islam mengatur bahwa untuk melaksanakan perkawinan harus ada : (1) Calon suami, (2) Calon istri, (3) Wali nikah, (4) Dua saksi, (5) Ijab dan Qobul

${ }^{6}$ Pasal 19 Undang-undang No. 1 Tahun 1974 tentang Perkawinan 
Adapun yang bertindak sebagai wali nikah yaitu wali nasab atau wali hakim. ${ }^{7}$ Wali yang paling utama ialah ayah, kakek (ayahnya ayah), saudara lelaki seayah seibu (kandung), saudara lelaki seayah, anak lelaki saudara lelaki seayah seibu (kandung), anak lelaki saudara lelaki seayah, paman dari pihak ayah, dan anak lelaki paman dari pihak ayah (Nasab). ${ }^{8}$ Wali hakim baru dapat bertindak sebagai wali nikah apabila wali nasab tidak ada atau tidak mungkin menghadirkannya atau tidak diketahui tempat tinggalnya atau gaib atau Adlal atau enggan. ${ }^{9}$

Permasalahan mengenai wali nasab yang enggan menikahkan anak perempuannya juga pernah terjadi di Kantor Urusan Agama (KUA) Kecamatan Tambun Selatan. Perkara wali Adlal yang terjadi di KUA Kecamatan Tambun Selatan diajukan pada bulan Maret Tahun 2021, dari sepasang calon pengantin mempelai pria berusia 27 tahun dan mempelai wanita berusia 22 tahun untuk dinikahkan. Dalam pertimbangan bahwa berdasarkan pemeriksaan identitas ternyata pemohon bertempat tinggal di Kelurahan Tridaya. Maka berdasarkan PMA No.2 tahun 1987 Tentang Wali Nikah dan PMA No.11 tahun 2007 Tentang Percatatan Nikah, perkara ini menjadi wewenang KUA Kecamatan Tambun Selatan. Adapun faktor keengganan wali pemohon enggan menikahkan anak perempuan dibawah perwaliannya disebabkan oleh pertimbangan orang tua mengenai bibit, bebet dan bobot calon menantu dimana sang calon menantu bukan berasal dari kalangan ekonomi atas seperti yang diharapkan oleh orang tua pihak wanita. Pada dasarnya penolakan wali untuk menikahkan anak perempuannya dilarang oleh agama karena merupakan perbuatan zalim. ${ }^{10}$ Wali sesungguhnya dilarang mempersulit perkawinan perempuan yang berada dalam perwaliannya sepanjang mendapat pasangan yang sekufu' baik dari segi agama, nasab, pendidikan, ekonomi dan lain-lain.

Berdasarkan penelitian yang telah dilakukan sebelumnya, maka terdapat perbedaan yang menjadi fokus penelitian saat ini. Walaupun tema yang diambil memiliki keterkaitan yakni tentang wali adhal, namun penelitian ini lebih kearah yuridis normatif. Maka dapat dirumuskan permasalahan yang perlu dikaji, yaitu bagaimana menurut UU Perkawinan tahun 1974 dan Kompilasi Hukum Islam mengenai wali Adlal maka apakah bisa dilakukan pencegahan atau pembatalan perkawinan. Tujuan penelitian ini untuk mengetahui pandangan mengenai adhalnya wali karena alasan tidak di setujui oleh oran tua nya.

\footnotetext{
${ }^{7}$ Pasal 20 Kompilasi Hukum Islam

${ }^{8}$ Pasal 21 Kompilasi Hukum Islam. Lihat juga https://islam.nu.or.id/post/read/84172/syarat-danurutan-yang-berhak-jadi-wali-nikah

${ }_{9}^{9}$ Pasal 23Kompilasi Hukum Islam

${ }^{10}$ Data ini diperoleh melalui serangkaian wawancara dengan bapak azizah, Calon mertua di Bekasi Tambun Selatan Januari 2021
} 
Berkaitan dengan masalah perpindahan dari wali nasab yang disebabkan oleh wali Adlal ke wali hakim dalam suatu pernikahan yang berlaku di Indonesia, juga dinyatakan dalam Kompilasi Hukum Islam ayat 2 Pasal 23 yakni: "Wali hakim dapat bertindak sebagai wali nikah apabila wali nasab tidak ada atau tidak mungkin menghadirkannya atau tidak diketahui tempat tinggalnya atau ghaib atau Adlal atau keberatan".

Apabila terjadinya pencegahan dan pembatalan perkawinan di lakukan karena menggunakan wali Adlal maka pernikahan itu tidak dapat dibatalkan karna belum termaksud larangan perkawinan berdasarkan undang-undang perkawinan tahun 1974 Pasal 8 dan Kompilasi Hukum Islam Pasal 39 dan 44. Oleh karna itu calon mempelai harus memenuhi syarat-syarat perkawinan.

Dalam hal wali Adlal atau keberatan maka wali hakim baru dapat bertindak sebagai wali nikah setelah ada Putusan dari Pengadilan Agama tentang wali tersebut. ${ }^{11}$ Di dalam praktik pelaksanaannya perpindahan wali nasab kepada wali hakim dapat menimbulkan permasalahan di kemudian hari yang memerlukan pemecahan. Sebab, eksistensi keberadaan wali dalam sebuah pernikahanan merupakan komponen yang harus ada, dimana jika wali nasab tidak ada, maka yang dapat menggantikan posisinya adalah wali hakim, namun seorang wali hakim tidak dapat serta merta menjadi wali selama masih ada wali nasab yang lebih dekat (aqrab) dan yang jauh ( $\left.a b^{\prime} a d\right)$.

Menurut pendapat imam Syafi'i dan Hambali bahwa wali yang paling berhak menikahkan wanita adalah wali dekat (aqrab) kemudian wali jauh $\left(A b^{\prime} a d\right)$ jika tidak ada maka yang berhak menikahkan adalah penguasa (Wali hakim). ${ }^{12}$ Keberadaan wali hakim sabagai pengganti wali Adlal harus sesuai dengan ketentuan yang berlaku sehingga pernikahan yang dilakukan dianggap sah baik dimata agama ataupun dimata hukum hal ini disukung oleh pendapat bahwa suatu perkawinan akan dianggap sah atau mempunyai kekuatan hukum jika pelaksanaan pernikahan itu sesuai dengan peraturan dan ketentuan hukum Islam. ${ }^{13}$

Berkaitan dari realita tersebut, maka penulis tertarik untuk mengkaji lebih jauh tentang. penetapan wali hakim sebagai pengganti wali Adlal yang terjadi di KUA Kecamatan Tambun Selatan Kabupaten Bekasi. dalam penelitian dengan judul "PENETAPAN WALI HAKIM SEBAGAI PENGGANTI WALI ADLAL YANG TIDAK MENYETUJUI PERNIKAHAN ANAKNYA.”

${ }^{11}$ Tim Penulisan Yustisia. zeri Perundang -Undangan.Jakarta: Gramedia, 2005, hlm.58

12 Masyakur AB. Kamus hukum Fiqih Lima Mazhab.Jakarta: Lentera. 2000, hlm. 345

13 Rohmat, Kedudukan Wali dalam pernikahan: studi Pemikiran Syafi'iyah, Hanafiyah, dan Peraktiknya di Indonesia, (Fakultas Syari'ah dan Hukum Universitas Islam Negeri Sunan Kalijaga Yogyakarta 2011), (7 Juni2021) 


\section{METODE PENELITIAN}

Penulisan ini menggunakan metode penelitian hukum normative dengan spesifikasi penelitian deskriptif, mengedepankan data sekunder sebagai data utamanya yaitu, bahan hukum primer berupa Undang-Undang No. 1 Tahun 1974 tentang Perkawinan dan Kompilasi Hukum Islam (KHI), bahan hukum sekunder berupa buku-buku yang terkait, dan bahan hukum tersier berupa jurnal penelitian hukum dan artikel ilmiah lainnya. Data sekunder tersebut dikumpulkan melalui teknik studi kepustakaan dan dikelompokkan sesuai jenis bahan hukum. Dengan menggunakan metode kualitatif menguraikan datadata ke dalam bentuk kalimat kalimat menjadi sebuah paragraph yang logis, sistematis, dan efektif. Kemudian diambil kesimpulan secara deduktif sebagai jawaban adhalnya wali ditinjau dari perspektif, dalam hukum Islam. Pengumpulan data dalam penelitian ini melalui metode pendekatan diantaranya: pendekatan perundang-undangan (statute approach), pendekatan kasus (case approach), pendekatan konseptual (conseptual approach).

\section{PEMBAHASAN}

\section{Analisis Penetapan Wali hakim Sebagai Pengganti Wali Adlal Menurut UU Perkawinan dan Kompilasi Hukum Islam}

Perkawinan menurut Undang-undang No. 1 Tahun 1974 didefinisikan sebagai : "ikatan lahir batin antara seorang pria dengan seorang wanita sebagai suami isteri dengan tujuan membentuk keluarga, rumah tangga yang bahagia dan kekal berdasarkan Ketuhanan Yang Maha Esa". ${ }^{4}$ Menurut etimologi para ulama fikih diantaranya Imam Hanafiah mendefinisikan perkawinan "nikah adalah akad yang memberi faedah untuk melakukan mut'ah secara sengaja" artinya kehalalan seorang laki-laki untuk melakukan beristimta' dengan seorang wanita selama tidak ada faktor yang menghalangi sahnya pernikahan tersebut secara syar'i. ${ }^{15}$

Dalam ikatan 'perkawinan' sebagai salah-satu bentuk perjanjian (suci) antara seorang pria dengan seorang Wanita, yang mempunyai segi-segi perdata, dan Asas Kompilasi Hukum Islam berlaku beberapa asas di antaranya adalah (1) kesukarelaan, (2) persetujuan kedua belah pihak, (3) kebebasan memilih, (4) kemitraan suami-istri, (5) untuk

14 Pasal 1ayat (2) Undang-Undang Nomor 1 Tahun 1974, Tentang Perkawinan

${ }_{15}$ Amir Nuruddin dan Azhari Akmal Tarigan, Hukum Perdata Islam di Indonesia, Jakarta: Kencana Prenadamedia Group, 2004, hlm. 38 
selama-lamanya, dan (6) monogami terbuka (karena darurat). Adapun keabsahan suatu perkawinan apabila dilakukan menurut hukum masing-masing agamanya dan kepercayaannya itu serta dicatat menurut peraturan perundang-undangan yang berlaku.

Meskipun perkawinan telah memenuhi rukun dan syarat yang ditentukan belum tentu perkawinan tersebut sah, karena masih tergantung lagi pada satu hal, yaitu perkawinan itu telah terlepas dari segala hal yang menghalang. Halangan perkawinan itu disebut juga dengan larangan perkawinan yaitu orang-orang yang tidak boleh melakukan perkawinan, diantaranya:

1. Larangan perkawinan yang berlaku haram untuk selamanya disebut mahram muabad. Yang dipengaruhi oleh nasab diantaranya: ibu, anak perempuan, bibi, dari jalur ayah, bibi dari jalur ibu, anak perempuan dari saudara laki-laki, anak perempuan dari saudara perempuan.

2. Larangan perkawinan berlaku untuk sementara waktu dalam arti larangan itu berlaku dalam keadaan dan waktu tertentu; suatu ketika bila keadaan dan waktu tertentu itu sudah berubah ia tidak lagi menjadi haram, disebut mahram muaqqat. Yang di pengaruhi bibi istri, perempuan yang kelima, perempuan musyrik penyembah berhala, perempuan bersuami, dan perempuan yang menjalankan masa iddah. ${ }^{16}$

Adapun larangan perkawinan menurut Undang-Undang No. 1 Tahun 1974 pasal 8 bahwa perkawinan yang menentukan bahwa perkawinan dilarang dua orang yang: ${ }^{17}$

1 Berhubung dalam darah garis keturunan lurus ke bawah ataupun keatas;

2 Berhubungan darah dalam garis keturunan menyamping yaitu antara saudara orang tua dan antara seorang dengan saudara neneknya;

3 Berhubungan Semenda, yaitu mertua, anak tiri menantu dan ibu/bapak tiri;

4 Berhubungan Susuan, yaitu orang tua susuan, anak susuan, saudara susuan bibi/paman susuan;

5 Berhubungan saudara dengan isteri atau sebagai bibi atau kemenakan dari isteri dalam hal seorang suami beristeri lebih dari seorang;

6 Mempunyai hubungan yang oleh agamanya atau peraturan lain yang berlaku, dilarang kawin.

Menurut Kompilasi Hukum Islam larangan perkawinan telah diatur dalam pasal 39 sampai 44 yaitu :

16 Amir Syarifudin, Op.Cit., hlm. 109-110

17 Pasal 8 Undang-Undang No. 1 tahun 1974 tentang Perkawinan 
1 perkawinan dilarang antara seorang pria dengan seorang wanita disebabkan pertalian nasab, kerabat semenda, sesusuan ${ }^{18}$

2 karena keadaan tertentu; wanita masih terikat satu perkawinan dengan pria lain, seorang wanita dalam masa iddah dengan pria lain, seorang wanita yang tidak beragama islam.

3 Seorang pria dilarang memadu isterinya dengan seoarang wanita yang mempunyai hubungan pertalian nasab atau sesusuan dengan isterinya;

4 pria melangsungkan perkawinan sedang mempunyai 4 (empat) orang isteri yang keempat-empatnya masih terikat tali perkawinan.

5 perkawinan seorang pria dengan seorang wanita bekas isterinya yang ditalak tiga kali; dengan seorang wanita bekas isterinya yang dili`an.

6 Seorang wanita Islam dilarang melangsungkan perkawinan dengan seorang pria yang tidak beragama Islam.

\section{Syarat Perkawinan}

Syarat-Syarat Menurut Undang-Undang No 1 Tahun 1974 diatur dalam pasal 6 sampai dengan Pasal 12 sebagai berikut :

1. Ada persetujuan kedua calon mempelai (Pasal 6 ayat (1)).

2. Adanya persetujuan dari kedua orang tua/ wali calon mempelai yang belum berusia 21 tahun (Pasal 6 Ayat (1),(2),(3),(4),(5), dan (6)).

3. Usia calon mempelai sudah 19 tahun dan usia calon Wanita sudah 16 tahun (Pasal 7 ayah (1)).

4. Antara calon mempelai pria ataupun wanita tidak memiliki darah keturunan/ Keluarga tidak boleh kawin (Pasal 8).

5. Tidak berada ikatan perkawinan dengan pihak lain (Pasal 9)

6. Bagi suami istri yang bercerai, lalu kawin lagi agama mereka tidak menyetuji untuk menikah 3 kalinya (Pasal 10).

7. Tidak ada waktu tunggu bagi calon mempelai Wanita yang janda.

Di dalam Kompilasi Hukum Islam pasal 14 menyatakan bahwa untuk melaksanakan perkawinan harus ada : (1) Calon suami, (2) Calon istri, (3) Wali nikah, (4) Dua saksi, (5) Ijab dan Qobul. ${ }^{19}$ Dalam perkawinan adakalanya tidak sesuai yang diharapkan sehingga terjadi pencegahan bahkan pembatalan perkawinan.

18 Pasal 39-44 Kompilasi Hukum Islam

${ }^{19}$ Pasal 14 Kompilasi Hukum Islam 
Pencegahan perkawinan adalah usaha untuk membatalkan perkawinan sebelum perkawinan itu berlangsung, dalam Pasal 13 Undang-Undang Perkawinan, perkawinan dapat dicegah apabila ada pihak yang tidak memenuhi syarat-syarat melangsungkan perkawinan. ${ }^{20}$ Adapun pembatalan perkawinan adalah pembatalan hubungan suami istri sesudah dilangsungkannya akad nikah. ${ }^{21}$ Menurut hukum Islam suatu perkawinan dapat batal dan dibatalkan, perkawinan yang melanggar larangan yang bersifat abadi, yakni yang berkaitan dengan hukum agama dalam perkawinan, maka pembatalannya bersifat abadi. Sedangkan yang melanggar larangan yang bersifat sementara, yakni larangan yang adakalanya berhubungan dengan agama dan administrasi. ${ }^{22}$

Menurut Kompilasi Hukum Islam, Wali nikah dalam perkawinan merupakan rukun yang harus dipenuhi bagi calon mempelai waita yang bertindak untuk menikahkannya. Yang bertindak sebagai wali nikah ialah seorang laki-laki yang memenuhi syarat hukum Islam yakni muslim, aqil dan baligh. Wali Nikah Terdiri dari : Wali Nasab, Wali Hakim.

Urutan wali nikah berdasarkan Kompilasi Hukum Islam diatur dalam pasal 21 dan $22:^{23}$ Wali nasab terdiri dari empat kelompok sesuai erat tidaknya susunan kekerabatan dengan calon mempelai wanita.

1. Pertama, kelompok kerabat laki-laki garis lurus keatas yakni ayah, kakek dari pihak ayah dan seterusnya.

2. Kedua, kelompok kerabat saudara laki-laki kandung atau saudara lakilaki seayah, dan keturunan laki-laki mereka.

3. Ketiga, kelompok kerabat paman, yakni saudara laki-laki kandung ayah, saudara seayah dan keturunan laki-laki mereka

4. Keempat, kelompok saudara laki-laki kandung kakek, saudara lakilaki seayah dan keturunan laki-laki mereka

Apabila wali-wali tersebut di atas tidak ada atau ada hal-hal lain yang menghilangkan hak kewaliannya, maka hak perwalian tersebut pindah kepada wali hakim. Hal ini sebagaimana dijelaskan dalam pasal $23 \mathrm{KHI}$ :

1 Wali hakim baru dapat bertindak sebagai wali nikah apabila wali nasab tidak ada atau tidak mungkin menghadirinya atau tidak diketahui tempat tinggalnya atau gaib atau Adlal atau enggan.

\footnotetext{
20 Zainuddin Ali, Hukum Perdata Islam, Loc.Cit., hlm. 33

${ }^{21}$ Zainudin Ali, Hukum Perdata Islam di Indonesia, Jakarta: Sinar Grafika Offset, 2012.hlm. 37.

${ }^{22}$ Ibid, hlm. 42

${ }^{23}$ Ibid,
} 
2 Dalam hal wali Adlal atau enggan maka wali hakim baru dapat bertindak sebagai wali nikah setelah ada putusan pengadilan Agama tentang wali tersebut. ${ }^{24}$

Selanjutnya yang berhak menjadi Wali Hakim yaitu : Dalam hal ini KHI menjelaskan pada pasal 1 huruf b bahwa: "Wali hakim ialah wali nikah yang ditunjuk oleh Menteri Agama atau pejabat yang ditunjuk olehnya, yang diberi hak dan kewenangan untuk bertindak sebagai wali nikah" KHI memang tidak menyebutkan siapa yang ditunjuk oleh Menteri Agama untuk bertindak sebagai wali hakim, namun sebelum KHI lahir, telah ada Peraturan Menteri Agama yang menjelaskan hal ini. Pasal 4 Peraturan Menteri Agama No.2 Tahun 1987 menyebutkan :

1 Kepala Kantor Urusan Agama Kecamatan selaku Pegawai Pencatat Nikah ditunjuk menjadi wali hakim dalam wilayahnya untuk menikahkan mempelai wanita sebagai dimaksud pasal 2 ayat (1) peraturan ini.

2 Apabila Kepala Kantor Urusan Agama Kecamatan berhalangan atau tidak ada, maka Kepala Seksi Urusan Agama Islam Kabupaten atau Kotamadya diberi kuasa untuk atas nama Menteri Agama menunjuk wakil atau pembantu Pegawai Pencatat Nikah untuk sementara menjadi wali hakim dalam wilayahnya.

\section{Wali Adlal}

Kompilasi Hukum Islam tidak mengatur dengan jelas mengenai pengertian wali Adlal, tetapi secara bahasa Adlal adalah wali nasab yang tidak memenuhi syarat untuk menjadi seorang wali atau berhalangan atau mafqud. Jika wali tidak mau menikahkan, harus dilihat dulu alasannya, apakah alasan wali tersebut syar'i atau tidak syar'i. Alasan syar'i adalah alasan yang dibenarkan oleh hukum syara ${ }^{e e}$, misalnya anak gadis Wali tersebut sudah dilamar orang lain dan lamaran ini belum dibatalkan, atau calon suaminya adalah orang kafir (bukan muslim), atau orang fasik (misalnya pezina dan suka mabuk), atau mempunyai cacat tubuh yang menghalangi tugasnya sebagai suami, dan sebagainya. Jika wali menolak menikahkan anak gadisnya berdasarkan alasan syar'i seperti ini, maka wali wajib ditaati dan kewaliannya tidak dapat berpindah kepada pihak lain (wali hakim).

Ketentuan dalam Pasal 23 ayat (2) Kompilasi Hukum Islam tersebut di atas, apabila wali nasab Adlal atau enggan untuk menjadi wali maka wali hakim baru dapat bertindak sebagai wali calon mempelai perempuan. Setelah adanya penetapan Pengadilan Agama tentang wali Adlal, terlebih dahulu calon mempelai wanita mengajukan permohonan Adlalnya wali kepada Pengadilan Agama dimana pemohon bertempat

\footnotetext{
${ }^{24}$ Ibid., hlm. 20
} 
tinggal. Apabila hakim berpendapat bahwa wali benar-benar Adlal dan pemohon tetap pada permohonannya maka hakim akan mengabulkan pemohon dengan menetapkan Adlalnya wali dan menunjuk Kepala Kantor Urusan Agama Kecamatan, selaku Pegawai Pencatat Nikah di tempat tinggal pemohon untuk bertindak sebagai wali hakim.

\section{Wali Hakim}

Wali hakim merupakan wali bagi seseorang yang tidak memiliki wali nasab ataupun wali yang enggan menikahkan. Hadits riwayat Aisyah, Dari Aisyah ra berkata: "Perempuan mana saja yang menikah dengan izin walinya, maka pernikahannya batil, batil, dan batil. Jikadia digauli, maka dia berhak mendapatkan mahar akibat persetubuhan yang dilakukan kepadanya. Jika mereka berselisih maka penguasa adalah wali bagi orang yangtidak memiliki wali."

Syarat-syarat Wali Hakim Adapun mengenai pernikahan menggunakan wali hakim, apabila terjadi hal-hal sebagai berikut $:^{25}$

1 Tidak ada wali nasab.

2 Tidak cukup syarat-syarat pada wali aqrab atau wali ab"ead.

3 Wali aqrab gaib atau pergi dalam perjalanan sejauh $+92,5 \mathrm{~km}$ atau dua hari perjalanan.

$4 \quad$ Wali aqrab di penjara atau tidak bisa ditemui.

5 Wali aqrabnya Adlal.

6 Wali aqrabnya mempersulit.

7 Wali aqrabnya sedang dalam ihram.

8 Wali aqrabnya sendiri yang akan menikah.

9 Wanita yang akan dinikahkan gila, tetapi sudah dewasa dan wali mujbir tidak ada.

Wali hakim tidak berhak menikahkan apabila sebagai berikut:

1 Wanita yang akan dinikahkan belum balig.

2 Kedua belah pihak mempelai tidak sekufu (sederajat).

3 Tanpa seizin wanita yang akan menikah (mantan istrinya).

4 Di luar daerah kewenangannya.

25 Slamet Abidin dan Aminudin, Fiqib Munakahat 1, Bandung: CV Pustaka Setia, 1999, hlm. 92 
KRTHA BHAYANGKARA | Volume 15 Number 2, December 2021

\section{Sekufu}

Menurut KKBI Sekufu Sederajat, Adapun maksud sekufu dalam perkawinan di sini adalah sepadannya seorang suami dengan istrinya dalam agama, kedudukan, pendidikan, kekayaan, status sosial, dan sebagainya. Menurut mazhab Syafi'i berpendapat bahwa sekufu artinya sepadan dalam empat hal yakni kesepadanan nasab, agama, strata sosial (merdeka atau budak), dan pekerjaan.

Kategori sekufu disini diukur pada kesepadanan terhadap nilai-nilai sosial dan tradisi masyarakat setempat. Misalnya keturunan, profesi, status sosial, kekayaan dan lain-lain. Unsur ini tidak semua ulama sependapat akan kekufuannya untuk diterapkan dalam pernikahan. Kriteria tersebut akan peneliti jelaskan ${ }^{26}$, sebagai berikut:

1 Nasab/Keturunan, adalah asal usul atau keturunan seseorang yaitu keberadaan seseorang berkenaan dengan latar belakang keluarganya baik menyangkut kesukuan, kebudayaan maupun status sosialnya. ${ }^{27}$

2 Pekerjaan, orang yang memiliki pekerjaan yang rendah seperti tukang bekam atau tukang kebun, tidaklah sepadan dengan putri seorang yang memiliki pekerjaan besar seperti saudagar dan pedagang kaya. ${ }^{28}$

3 Merdeka, orang yang mempunyai status sebagai hamba sahaya atau seorang budak belia tidaklah sepadan dengan orang yang merdeka. Karena ia memiliki kekurangan statusnya dalam kepemilikan orang lain. Perbudakan diartikan dengan kurangnya kebebasan. ${ }^{29}$

4 Kekayaan, adalah kemampuan seseorang untuk membayar mahar dan memenuhi nafkah. ${ }^{30}$

5 Bebas dari Cacat, adalah keadaan yang dapat memungkinkan seseorang untuk dapat menuntut faskh. Karena orang cacat dianggap tidak sekufu' dengan orang yang tidak cacat. Adapun cacat yang dimaksud adalah meliputi semua bentuk cacat baik fisik maupun psikis yang meliputi penyakit gila kusta atau lepra. Kriteria hanya diakui oleh ulama Malikiyah tetapi dikalangan sahabat Imam Syafi'i ada juga yang mengakuinya. ${ }^{31}$

${ }^{26}$ Ikhwani, Kafa'ah Dalam Perkawinan, Dalam Jurnal Ilmiah Sains, Teknologi, Ekonomi, Sosial Dan Budaya, Jakarta: 2000 hlm. 21.

${ }^{27}$ Mizan, Aktualisasi Konsep Kafa'ah Membangun Keharmonisan Rumah Tangga, Dalam Jurnal Imu Syariah, Bogor: FAI Unifersitas Ibn Kholdun, 2016. hlm.42

${ }^{28}$ Siti Zulaikha, Op.Cit., hlm. 46

${ }^{29}$ Ibid,

${ }^{30} \mathrm{Ibid}$,

${ }^{31}$ Ibid, 
Menurut Teori Keseimbangan Teori Heider berkepentingan secara khusus dengan apa yang diartikan sebagai komunikasi intra-pribadi, yaitu sangat menaruh perhatian pada keadaan-keadaan intra-pribadi yang mungkin mempengaruhi pola-pola hubungan dalam suatu kelompok. Keadaan seimbang dapat dikatakan, jika individuindividu didalam suatu kelompok saling menyukai. Misalnya, anda menyukai individu-individu kelompok anda dan individu individu tersebut juga menyukai anda. Jika mengacu asas kesukarelaan akan terjalin suatu hubungan yang baik antara anda dengan kelompok anda dan efek dari keadaan ini akan menciptakan kerja sama yang baik.

Teori Keseimbangan kata dasarnya adalah imbang, yang artinya sama. Kemudian kata imbang mendapat awalan se menjadi seimbang, yang artinya sebanding, selanjutnya kata seimbang tersebut mendapatkan imbuhan lagi yaitu ke-an sehingga menjadi keseimbangan dalam kasus ini mengenai imbang pada dasar Keadaan seimbang dapat dikatakan, jika individu individu didalam suatu kelompok saling menyukai. Misalnya, anda menyukai individu-individu kelompok anda dan individu individu tersebut juga menyukai anda. Maka akan terjalin suatu hubungan yang baik antara anda dengan kelompok anda dan efek dari keadaan ini akan menciptakan suatu keluarga yang baik.

Menurut Teori Ratio Decidendi adalah penafsiran hakim atau pertimbangan hakim yang dijadikan sebagai dasar pertimbangan oleh para pembentuk undang-undang. Dalam kasus ini penafsiran hakim menolak dengan berdasarkan. Menurut Keputuasan Pengadilan agama yang berwenang Bahwa Pemohon dengan surat permohonannya tertanggal 24 Maret 2021, yang telah terdaftar di Kepaniteraan Pengadilan Agama Cikarang, dalam register Nomor: 49/Pdt.P/2021/PA. Ckr tanggal 24 Februan 2021, mengemukakan hal-hal sebagai berikut :

1. Bahwa Pemohon adalah anak kandung dari pasangan:

1) Ayah dari Mempelai Wanita, Lahir di Jakarta, 09 Desember 1967, umur 52 tahun, Pekerjaan Wiraswasta, Pendidikan terakhir SLTA, tempal tinggal di Kampung Buwek Jaya RT 002 RW 002 Desa Tridayasakti, Kecamatan Tambun Selatan, Kabupaten Bekast, selanjutnya disebut Wali Pemohon. ${ }^{32}$

2) Ibu dari Mempelai Wanita, Lahir di Bandung 26 Februari 1969. umur 50 tanun pekerjaan Karyawan Swasta. Pendidikan terakhir SLTA, tempat tinggal di Kampung Buwek Jaya RT,002 RW 002 Desa Tridayasakti, Kecamalan Tambun Belatan Kabupaten Bekasi.

${ }^{32}$ Halaman 1, Penetapan Nomor 224/Pdt.P/2020/PA. Ckr. 
2. Bahwa Pemohan bermaksud akan melangsungkan pemikahan dengan seorang laki-laki pilihan bernama :

1. Calon mempelai pria, lahir di Bekasi, 03 Maret 1994, umur 25 tahun, agama Islam, pendidikan teerakhir SLTA, pekerjaan Karyawan Swasta, tempat tinggal di Kampung Sluke RT 008 RW 001 Desa Sluke Kecamatan Sluke, Kabupaten Rembang, Provinsi Jawa Tengah.

2. Bahwa antara Pemohon dengan calon suami sudah saling mencintai, sehingga Permohon bermiat melangsungkan pemikahan.

3. Bahwa ayah kandung kandung Pemohon tidak diketahui keberadaannya.

4. Bahwa antara Pemohon dengan calon suami Pemohon sudah merasa sekufu dan tidak ada larangan untuk melangsungkan Pernikahan serta semua syarat pernikahan terpenuhi.

5. Bahwa, untuk kepentingan proses pernikahan, Pemohon dan calon suami Pemohon telah mengurus administrasi dan pendaftaran rencana pemikahan Pemohon dengan calon suami Pemohon.

6. Bahwa Pemohon dan calon suami Pemohon khawatir melakukan perbuatan melanggar hukum agama dan Negara, maka Pemohon dengan calon suami Pemohon dalam waktu dekat akan segera melangsungkan pernikahan di Kecamatan Setu Kabupaten Bekasi, maka Pemohon agar Majelis Hakim Pengadilan Agama Cikarang berkenen menetapkan Adhalnya sebagai Wali Hakim dalam Pemikahan Pemohon dan calon suami Pemohon.

Dalam penyelesaian perkara wali Adlal yang terjadi di KUA Tambun Selatan dimana perwaliannya berpindah kepada wali hakim didasarkan pada saksi yang ada serta pertimbangan hukum penetapan wali Adlal mendasarkan pada Undang-undang No. 1 Tahun 1974 tentang perkawinan, Peraturan Menteri Agama Nomor 2 Tahun 1987 tentang Wali Hakim, Peraturan Menteri Agama Nomor 11 Tahun 2007 tentang Pencatatan Nikah dan Kompilasi Hukum Islam (KHI) dan firman Allah SWT dalam Al-Quran Surah ke 2 Al-Baqarah ayat 232. Dalam hal ini tentu status wali hakim sebagai pengganti wali Adlal telah sesuai dengan apa yang tercantum di dalam KHI pasal 23.

Fikih munakahat (Hukum Islam) menjadi rujukan dalam ketentuan Kompilasi Hukum Islam (KHI), dengan demikian pratktik wali hakim sebagai pengganti wali Adlal yang terjadi di KUA Tambun Selatan dipandang sah oleh Kompilasi Hukum Islam, sebab perpindahan hak perwalian ke wali hakim tersebut sesuai dengan ketentuan yang ada dalam UU Perkawinan dan Kompilasi Hukum Islam (KHI) yang menerangkan tentang 
larangan wali untuk menghalang halangi pernikahan seorang perempuan yang berada dalam perwaliannya terlebih jika keduanya (pihak perempuan dan calon suami) bertekad untuk menjalin hubungan rumah tangga yang baik.

Teori Perlindungan Hukum Menurut Sajtipto Rahardjo bahwa perlindungan hukum adalah memberikan pengayoman kepada hak asasi manusia yang dirugikan orang lain dan perlindungan tersebut diberikan kepada masyarkat agar mereka dapat menikmati semua hak-hak yang diberikan oleh hukum. ${ }^{33}$ Terkait adanya perkawinan yang tidak dicatatkan, berakibat pada perkawinan itu sendiri dan keturunan yang dilahirkan dari perkawinan yang tidak dicatatkan. Akibat hukumnya sangat kompleks terkait status, harta benda, hak waris dan lain sebagainya, maka dari itu perlu adanya perlindungan hukum. Arti sempit dari perlindungan, hanya perlindungan oleh hukum saja, yang terkait dengan adanya hak dan kewajiban, yang dimiliki oleh manusia sebagai subyek hukum dalam interaksinya dengan manusia lain serta lingkungannya. Sebagai subyek hukum manusia memiliki hak dan kewajiban untuk melakukan suatu tindakan hukum ${ }^{34}$

Bahwa Perkawinan merupakan akad yang sangat kuat (mitsâqan galidzhan) antara seorang laki-laki dengan seorang perempuan sebagai wujud ibadah kepada Allah SWT untuk membentuk keluarga yang sakinah, mawaddah, wa rohmah. Definisi tersebut paling tidak yang dimaksudkan oleh Pasal 1 Undang-Undang Nomor 1 Tahun 1974 tentang Perkawinan dan Pasal 2 Kompilasi Hukum Islam yang diberlakukan melalui Instruksi Presiden RI Nomor 1 Tahun 1991[2]. Dari definisi tersebut, dapat dipahami bahwa dalam suatu perkawinan, terdapat beberapa unsur mendasar, yaitu 1) adanya ikatan lahir bathin yang kuat antara seorang laki-laki dengan seorang perempuan;2) pelaksanaannya merupakan wujud dari ibadah kepada Allah SWT; dan3) bertujuan untuk membentuk keluarga yang sakinah, mawaddah, wa rohmah.

Dalam Pasal 23 ayat (2), KHI mengatakan: "Dalam hal wali Adlal atau enggan maka wali hakim baru dapat bertindak sebagai wali nikah setelah ada putusan Pengadilan Agama tentang wali tersebut”. Di dalam memeriksa dan menetapkan perkara, Pegadilan Agama wajib memberikan pelayanan hukum dan keadilan dengan mewujudkan peradilan yang mandiri dan independen, bebas dari campur tangan pihak lain. Serta melaksanakan kekuasaan kehakiman yang mandiri, tidak memihak dan transparan. ${ }^{35}$

Dalam kasus ini pertimbangan hukum dapat diketahui bahwa para pemohon telah melangsungkan pernikahan menurut agama islam. secara keseluruhan tidak bertentangan

${ }^{33}$ Sajtipto Rahardjo, Konsep Hukum Progresif, Yogyakarta: Genta Publishing, 2009, hlm. 20

${ }^{34}$ CST Kansil, Pengantar Ilmu Hukum dan Tata Hukum Indonesia, Jakarta: Balai Pustaka, 1989, hlm. 35

35 M. Mursyid Asyari, Op.cit.., hlm. 32 
dengan aturan pernikahan hukum Islam namun berdasarkan posita para pemohon dalam surat permohonan disana tidak disebutkan bahwa pernikahan tersebut dilaksanakan di rumah mempelai dan tidak di hadirkan pegawai pencatat nikah dari KUA setempat sehingga dapat disimpulkan bahwa pernikahan para pemohon adalah pernikahan dibawah tangan.

\section{Analisis Upaya Wali Adlal Apakah dapat Melakukan Pencegahan dan Pembatalan Perkawinan}

Perpindahan dari wali nasab yang disebabkan keAdlalan wali pemohon kepada wali hakim yang terjadi di KUA Tambun Selatan memiliki dasar bahwa dalam sebuah perkawinan keberadaan wali sangatlah penting. Wali yang paling berhak untuk menikahkan anak perempuannya dalah wali nasab, sedangkan dalam perkara ini, wali nasab bersikap enggan atau menolak untuk menikahkan, maka berdasrkan hukum shar'i dan juga hukum positif yang berlaku di Indonesia, hak perwalian tersebut dapat berpindah ke tangan wali hakim.

Wali merupakan salah satu unsur penting dalam suatu akad nikah. Sebagaimana pendapat ulamaee yang dianut oleh mayoritas umat Islam di Indonesia, bahwa suatu pernikahan tidak sah tanpa adanya wali. Kendatipun demikian, dalam kenyataan kadang terjadi bahwa wali, karena alasan tertentu enggan menikahkan anak perempuannya, sedangkan anak perempuan tersebut telah bersikeras untuk tetap menikah dengan calon suami pilihannya. Sehingga untuk bisa tetap melangsungkan pernikahan, calon mempelai perempuan harus mengajukan perkara tersebut ke Pengadilan Agama setempat agar menetapkan Adlalnya wali serta mengangkat wali hakim untuk menikahkannya.

Dasar yang digunakan Majelis Hakim untuk menetapkan Adlalnya wali adalah buktibukti serta fakta-fakta hukum yang berkaitan dengan perkara tersebut. Hal ini sesuai dengan pasal 163 HIR yang menyatakan bahwa: Barang siapa yang mengatakan ia mempunyai hak, atau ia menyebutkan suatu perbuatan untuk menguatkan haknya itu, atau untuk membantah hak orang lain, maka orang itu harus membuktikan adanya hak itu atau adanya kejadian itu. Alat bukti dalam hal ini berupa bukti surat dan saksi. Bukti surat yang pokok dalam perkara wali Adlal adalah surat penolakan pernikahan yang dikeluarkan oleh Kantor Urusan Agama setempat. Sedangkan saksi adalah orang-orang yang mengetahui adanya permasalahan tersebut, dan saksi-saksi akan dimintai keterangan mengenai keengganan wali dan juga keadaan kedua calon mempelai. Karena salah satu wewenang Pengadilan Agama adalah memberikan pelayanan hukum dan keadilan bagi mereka yang beragama Islam, maka dasar dan pertimbangan yang digunakan untuk menyelesaikan suatu perkara adalah hukum Islam. 
Pencegahan perkawinan ialah usaha ntuk membatalkan perkawinan sebelum perkawinan itu berlangsung. Perncegahan perkawinan itu dapat dilakukan apabila calon suami atau calon istri yang akan melangsungkan perkawinan berdasarkan hukum Islam yang termuat dalam Pasal 13 Undang-Undang Perkawinan, yaitu perkawinan dapat dicegah apabila ada pihak yang tidak memenuhi syarat-syarat melangsungkan perkawinan. Dalam hal ini calon mempelai memenuhi syarat Perkawinan sehingga bisa melangsungkan perkawinan maka pencegahan tidak dapat dilakukan dari seorang ayah. Karna mereka saling mencitai satu sama lain sebagai mana yang ditrapkan dengan penetapan di atas. Dalam larangan perkawinan pasal 8 UU Perkawinan 1974 menentukan bahwa perkawinan dilarang antara dua orang yang (1) Berhubungan darah dalam garis keturunan lurus kebawah ataupun keatas, (2) Berhubungan darah dalam garis keturunan menyamping yaitu antara saudara. Dalam Agama Islam tentang Kompilasi Hukum Islam larangan perkawinan pada pasal 39 sampai 44. Dalam hal ini calon mempelai tidak memiliki unsur larangan perkawinan, yang di maskud hukum positif.

Pencegahan perkawinan yang dapat dilakukan pegawai pencatat perkawinan berkenaan dengan pelanggaran: calon mempelari belum cukup umur (19 tahun bagi pria dan 16 tahun bagi wanita), terkena larangan melangsungkan perkawinan, terikat tali perkawinan dengan orang lain, dan tidak memenuhi tata cara pelaksanaan perkawinan yang diatur dalam hukum. Dalam kasus ini kedua mempelai sudah mencukupi umur sehinggap dapat melangsungkan perkawinan secara sah.

Pembatalan perkawinan adalah pembatalan hubungan suami istri sesudah dilangsungkannya akad nikah. Adapun perkawinan yang dapat dibatalkan adalah seperti yang terdapat di dalam undang-undang perkawinan. Di antaranya adalah Pasal 22 "Perkawinan dapat dibatalkan apabila para pihak tidak memenuhi syarat-syarat untuk melangsungkan perkawinan”. Pasal 24 "Barang siapa karena perkawinan masih terikat dirinya dengan salah satu dari kedua belah pihak dan atas dasar masih adanya perkawinan dapat mengajukan pembatalan perkawinan yang baru dengan tidak mengurangi ketentuan Pasal 3 ayat (2) dan Pasal 4 undang-undang ini. Hak untuk membatalkan oleh suami atau istri berdasarkan alasan dalam ayat 1 pasal ini gugur apabila mereka telah hidup bersama sebagai suami istri dan dapat memperlihatkan akta perkawinan yang dibuat pegawai pancatat perkawinan yang tidak berwenang dan perkawinan harus diperbaharui supaya sah. Bahwa kasus yang di alami calon mempelai memenuhi syarat-syarat yang sudah di anjurkan maka pembatalan perkawinan tidak dapat dilakukan maka sang ayah mempelai Wanita harus bisa menerima calonnya sebagai dasar rasa kekeluargaan. 
Dalam Pencegahan dan Pembatalan tidak dapat dilakukan karna dalam hal ini kedua mempelai saling mencintai dan tidak ada larangan dalam agama yang diterangkan sebagai berikut, Meskipun perkawinan telah memenuhi rukun dan syarat yang ditentukan belum tentu perkawinan tersebut sah, karena masih tergantung lagi pada satu hal, yaitu perkawinan itu telah terlepas dari segala hal yang menghalang. Menurut pasal $13 \mathrm{UU}$ Perkawinan 1974 "Perkawinan dapat dicegah apabila ada pihak yang tidak memenuhi syarat-syarat perkawinan. Halangan perkawinan itu disebut juga dengan larangan perkawinan. Yang dimaksud dengan larangan perkawinan dalam bahasan ini adalah orangorang yang tidak boleh melakukan perkawinan. Berdasarkan yang dibicarakan disini ialah perempuan-perempuan mana saja yang tidak boleh dikawini oleh seorang laki-laki; atau sebaliknya laki-laki mana saja yang tidak boleh mengawini seorang perempuan.

Hal ini sejalan dengan kewenangan wali hakim sebagai wali nikah dimana menurut fiqih munakahat merupakan kewewenangan dari shari'at yang diberikan kepada Pemimpin atau Kepala Negara yang berfungsi sebagai pengganti wali nasab yang tidak dapat melaksanakan tugasnya sebagai wali nikah disebabkan oleh halangan-halangan yang dibenarkan oleh syar'i. Halangan-halangan tersebut dapat bersifat pribadi, salah satunya adalah disebabkan karena wali Adlal.

Berdasarkan hal tersebut maka, dalam perkara yang terjadi di KUA Tambun Selatan dimana wali nasab yang merupakan ayah dari pemohon enggan atau Adlal menikahkan anaknya maka dalam hal ini perwaliannya dapat berpindah ke tangan wali hakim sebagaimana yang disyariatkan dalam hukum Islam.

Kemudian untuk memutuskan siapakah yang paling tepat untuk ditunjuk sebagai wali hakim maka, sebagaimana termaktub dalam Kompilasi Hukum Islam Pasal 1 huruf b bahwa "Wali hakim ialah wali nikah yang ditunjuk oleh menteri agama atau pejabat yang ditunjuk olehnya, yang diberi hak dan kewenangan untuk bertindak sebagai wali nikah ". ${ }^{36}$ Maka, dalam hal ini yang paling berhak menjadi wali hakim dari pemohon adalah Kepala KUA Kecamatan Tambun Selatan.

Perpindahan dari wali nasab yang disebabkan keAdlalan wali pemohon kepada wali hakim yang terjadi di KUA Tambun Selatan memiliki dasar bahwa dalam sebuah perkawinan keberadaan wali sangatlah penting. Wali yang paling berhak untuk menikahkan anak perempuannya dalah wali nasab, sedangkan dalam perkara ini, wali nasab bersikap enggan atau menolak untuki menikahkan, maka berdasrkan hukum shar'i

${ }^{36}$ Ramulyo, Moh. Idris, Hukum Perkawinan Islam Jakarta: Bumi Aksara. 2004. hlm. 72 
dan juga hukum positif yang berlaku di Indonesia, hak perwalian tersebut dapat berpindah ke tangan wali hakim.

Sehingga dengan mempertimbangkan berbagai faktor, serta melihat alasan dibalik keAdlalan wali dan juga adanya keputusan dari Pengadilan agama Cikarang dengan Putusan Pengadilan Pengadilan Agama Nomor : 49/Pdt.P/2021/PA.Ckr. Maka secara otomatis hak perwalian dari wali nasab yang Adlal berpindah kepada wali hakim. Sehingga pelaksanaan akad nikah dapat dilakukan dengan wali hakim yang bertindak sebagai pengganti wali Adlal.

Terlebih lagi dalam perkara ini telah diputus mengenai keAdlalan wali berdasarkan dari keputusan Pengadilan agama wilayah setempat. Maka berdasarkan hal tersebut Kepala KUA Tambun Selatan dapat bertindak sebagai wali hakim atas nama calon mempelai wanita yakni mempelai wanita. Keberadaan wali hakim sabagai pengganti wali Adlal sudah sesuai dengan ketentuan yang berlaku sehingga pernikahan yang dilakukan dianggap sah baik dimata agama ataupun dimata hukum hal ini disukung oleh pendapat bahwa suatu perkawinan akan dianggap sah atau mempunyai kekuatan hukum jika pelaksanaan pernikahan itu sesuai dengan ketentuan dan peraturan yang telah ditetapkan oleh Sang Pembuat Hukum yakni Allah SWT.

\section{KESIMPULAN}

Setelah dilakukan peniltian mengenai praktik wali hakim sebagai pengganti wali Adlal menurut hukum Undang-Undang Perkawinan dan Kompilasi hukum Islam di KUA Kecamatan Tambun Selatan dan Pengadilan Agama Cikarang, dapat diambil kesimpulan bahwa:

Perpindahan hak perwalian dari wali nasab ke wali hakim dikarenakan wali Adlal yang diterapkan di KUA Kecamatan Tambun Selatan dilakukan melalui jalan mediasi antara ayah dan anak perempuannya, namun ayah selaku wali nasab masih tetap enggan menikahkan anaknya dengan alasan mahar yang di berikan dari laki-laki tidak sesuai ekspetasi ayahnya, dengan demikian pihak KUA menyarankan agar calon mempelai wanita mengajukan gugatan ke Pengadilan Agama Ciakarang Pengadilan Agama Nomor: 48/Pdt.P/2021/PA.Ckr mengabulkan gugatan calon mempelai wanita dengan memberi kewenangan kepada pihak KUA kecamatan Tambun Selatan untuk menunjuk wali hakim sebagai wali nikahnya dengan pertimbangan hukum penetapan wali Adlal majelis hakim mendasarkan pada Undang-undang No. 1 Tahun 1974 tentang perkawinan, Peraturan Menteri Agama Nomor 2 Tahun 1987 tentang Wali Hakim, Peraturan Menteri Agama 
Nomor 11 Tahun 2007 tentang Pencatatan Nikah, Kompilasi Hukum Islam (KHI) dan firman Allah SWT. Sehingga Penetapan Wali hakim Sebagai pengganti Wali Adlal sesuai dengan Undang-Undang Perkawinan dan Kompilasi Hukum Islam.

Bedasarkan hal-hal uraian yang di jelaskan sebelumnya dalam pencegahan dan pembatalan perkawinan tidak harus di cegah karna tidak termaksud Larangan Perkawinan di dasar kan pada UU Perkawinan tahun 1974 Pasal 8, dan Kompilasi Hukum Islam Pasal 39 sampai dengan 44 .

\section{Saran}

Kepada pihak calon mempelai perempuan seyogyanya meminta izin dan persetujuan dari wali nasab. karena wali nasab merupakan pemegang peran sah dan tidaknya akad nikah.

Kepada pihak wali nasab agar tidak berbuat adhal/enggan menikahkan anak kandungnya, karena yang demikian dapat memutuskan silaturrahmi dengan orang tua dan keluarga.

Dalam hal ini agar mempelai melakukan mekanisme Penikahan, dengan melakukan menikah ulang dengan wali hakim dari KUA sebagai mana Keputusan Pengadilan Agama.

\section{DAFTAR PUSTAKA}

\section{Buku}

Amir Syarifuddin, 2007. Hukum Perkawinan Islam di Indonesia. Jakarta: Kencana.

Amir Naruddin dan Azhari Akmal Taragi, 2004. Hukum Perkawinan Islam di Indonesia. Jakarta: Kencana.

CST Kansil, 1989, Pengantar Imu Hukum dan Tata Hukum Indonesia, Jakarta: Balai Pustaka. Hadikusuma, Hilman, 1990, Hukum Perkawinan Indonesia Menurut Undang-undang, Hukum Adat, Hukum Agama, Jakarta: Mandar Maju.

Ikhwani, 2000, Kafa'ah Dalam Perkawinan, J Teknologi, Ekonomi, Sosial Dan Budaya, Jakarta: Bumi Aksara

Masyakur AB, 2000, Kamus bukum Fiqib Lima Mą̧hab.Jakarta: Lentera.

Mizan, 2016, Aktualisasi Konsep Kafa'ab Membangun Keharmonisan Rumah Tangga, Bogor: FAI Unifersitas Ibn Kholdun.

Peter Mahmud Marzuki, 2017, Penelitian Hukum Edisi Revisi, Jakarta: Kencana.

R. Subekti dan R. Tjitrosubidio, 2005, Undang-Undang Nomor 1 Tabun 1974 Tentang Perkawinan, Jakarta: Pradnya Paramita. 
Ramulyo, Moh. Idris, 2004, Hukum Perkawinan Islam Jakarta: Bumi Aksara.

Sajtipto Rahardjo, 2009, Konsep Hukum Progresif, Yogyakarta: Genta Publishing.

Slamet Abidin dan Amindin, 2001 Fiqih Muakad. Bandung: CV Pustaka Setia.

Tim Penulisan Yustisia, 2005, zeri Perundang -Undangan.Jakarta: Gramedia.

Wahbah al Zuhailiy, 1997, al Figh al Islamiyah wa Adillatabubu, Juz 9. Dar al - Fikr: Beirut

Zainudin Ali, 2012. Hukum Perdata Islam Di Indonesia. Jakarta: Sinar Grafika Offset.

\section{Jurnal}

Rohmat, Kedudukan Wali dalam pernikahan: studi Pemikiran Syafi'iyah, Hanafiyah, dan Peraktiknya di Indonesia, (Fakultas Syari'ah dan Hukum Universitas Islam Negeri Sunan Kalijaga Yogyakarta 2011), (7 Juni2021).

Rohman. Adi Nur. (2019). The Existence Of Maslahah Mursalah As The Basis Of Islamic Law Development In Indonesia. Krtha Bhayangkara, 13(2). https://doi.org/10.31599/krtha.v13i2.9

Masri, E. (2019). Poligami Dalam Perspektif Undang-Undang Nomor I Tahun 1974 Tentang Perkawinan Dan Kompilasi Hukum Islam (KHI). Krtha Bhayangkara, 13(2). https://doi.org/10.31599/krtha.v13i2.7

\section{Peraturan Perundang-Undangan.}

Undang-Undang Dasar Negara Republik Indonesia Tahun 1945.

Undang-Undang Nomor 1 Tahun 1974 Tentang Perkawinan.

Undang-Undang PMA No 11 Tahun 2007 Tentang Pencatatan Nikah.

Undang-Undang PMA No 2 Tahun 1987 Tentang Wali Nikah.

\section{Wawancara}

Data ini diperoleh melalui serangkaian wawancara dengan orang tua mempelai wanita, calon mertua di Bekasi tambun selatan januari 2021. 